\title{
General aspects of muscle glucose uptake
}

\author{
RAFAEL O. ALVIM ${ }^{1}$, MARCEL R. CHEUHEN ${ }^{2}$, SILMARA R. MACHADO ${ }^{3}$, \\ ANDRÉ GUSTAVO P. SOUSA ${ }^{1,4}$ and PAULO C.J.L. SANTOS ${ }^{1}$ \\ ${ }^{1}$ Laboratório de Genética e Cardiologia Molecular, Instituto do Coração, Faculdade \\ de Medicina da Universidade de São Paulo, Av. Dr. Enéas de Carvalho Aguiar, 44, \\ Cerqueira César, 05403-000 São Paulo, SP, Brasil \\ ${ }^{2}$ Laboratório de Biodinâmica do Movimento Humano, Escola de Educação Física \\ e Esportes da Universidade de São Paulo, Av. Prof. Mello Moraes, 65, Cidade \\ Universitária, 05508-030 São Paulo SP, Brasil \\ ${ }^{3}$ Hospital Sírio Libanês, R. Adma Jafet, 91, Bela Vista, 01308-050 São Paulo, SP, Brasil \\ ${ }^{4}$ Departamento de Clínica Médica, Universidade Federal do Rio Grande do Norte, \\ Av. Nilo Peçanha, 620, Petrópolis, 59012-300 Natal, RN, Brasil
}

Manuscript received on May 6, 2014; accepted for publication on September 6, 2014

\begin{abstract}
Glucose uptake in peripheral tissues is dependent on the translocation of GLUT4 glucose transporters to the plasma membrane. Studies have shown the existence of two major signaling pathways that lead to the translocation of GLUT4. The first, and widely investigated, is the insulin activated signaling pathway through insulin receptor substrate-1 and phosphatidylinositol 3-kinase. The second is the insulin-independent signaling pathway, which is activated by contractions. Individuals with type 2 diabetes mellitus have reduced insulin-stimulated glucose uptake in skeletal muscle due to the phenomenon of insulin resistance. However, those individuals have normal glucose uptake during exercise. In this context, physical exercise is one of the most important interventions that stimulates glucose uptake by insulin-independent pathways, and the main molecules involved are adenosine monophosphate-activated protein kinase, nitric oxide, bradykinin, AKT, reactive oxygen species and calcium. In this review, our main aims were to highlight the different glucose uptake pathways and to report the effects of physical exercise, diet and drugs on their functioning. Lastly, with the better understanding of these pathways, it would be possible to assess, exactly and molecularly, the importance of physical exercise and diet on glucose homeostasis. Furthermore, it would be possible to assess the action of drugs that might optimize glucose uptake and consequently be an important step in controlling the blood glucose levels in diabetic patients, in addition to being important to clarify some pathways that justify the development of drugs capable of mimicking the contraction pathway.
\end{abstract}

Key words: diabetes, exercise, glucose uptake, diet, hypoglycemic drugs.

\section{INTRODUCTION}

The maintenance of stable levels of glucose is obtained by a complex homeostatic mechanism.

Correspondence to: Paulo Caleb Junior Lima Santos

E-mail: pacaleb@usp.br
During fasting, glucose is maintained via hepatic glycogenolysis or via gluconeogenesis. In a postprandial state, insulin is secreted from pancreatic $\beta$-cells and this hormone inhibits hepatic glucose output and promotes the glucose uptake 
into skeletal muscle and adipose tissue. In addition, insulin is important for several cellular processes, such as protein synthesis, gene transcription and metabolism. However, there are further glucose uptake mechanisms that have the purpose of maintaining glucose levels.

Disorders of glucose uptake by peripheral tissues are usually associated to pathological conditions such as obesity, atherosclerosis and type 2 diabetes mellitus (T2D). These conditions are frequently related to the inability of insulin to exert its role in glucose metabolism, especially in tissues with high metabolic activity (such as skeletal muscle), such phenomenon is known as insulin resistance (Razani et al. 2008, Rizza and Butler 1990, Westphal 2008). On the other hand, several studies have described important pathways by which glucose uptake is independent of the proper functioning of the insulin pathway (Lee et al. 1995) or the presence of any morbidity related to insulin resistance (Kennedy et al. 1999). In this context, exercise is one of the main interventions available because muscle contraction stimulates glucose uptake by insulin independent pathways (Lund et al. 1995) and the main molecules involved are adenosine monophosphate-activated protein kinase (AMPK), nitric oxide (NO), bradykinin, AKT, reactive oxygen species (ROS) and calcium. Interestingly, some previous studies showed that patients with T2D have similar composition of skeletal muscle fiber (Vogt et al. 1992, Zierath et al. 1996), expression of GLUT4 protein, and mRNA in response to exercise training (Dela et al. 1995, Hughes et al. 1993) compared with control subjects. With the better understanding about these pathways, it is possible to assess, exactly and molecularly, the importance of physical exercise and diet on glucose homeostasis. In addition, to test the action of drugs that might optimize glucose uptake and consequently be an important step in the control of blood glucose levels in diabetic patients (Musi et al. 2002), as well as to clarify some mechanisms of new drugs, such as PPAR $\delta$ and AMPK agonists (Narkar et al. 2008), that are commonly called the "exercise pills" and that are being studied in a future perspective for the treatment of T2D. Therefore, in this review, our main aims were to highlight the different glucose uptake pathways and to report the effects of exercise, diet and drugs on their functioning.

\section{GLUCOSE UPTAKE PATHWAYS}

\section{INSULIN-DEPENDENT PATHWAY}

Through an intracellular cascade reaction, insulin stimulates translocation of glucose transporters (GLUTs) into the cell membrane of the cells responsive to this hormone with subsequent internalization of glucose molecules (Cavalheira et al. 2002, Shepherd and Kahn 1999). In fact, considering all the effects of insulin on glucose metabolism, the regulation of GLUT4 trafficking and consequently glucose uptake is the most important of them (Rowland et al. 2011). In addition, glucose transport is the key step in insulin-regulated glucose metabolism, including glycolysis, glycogen synthesis and lipogenesis, and it is clear that a dysfunction in this process in muscle and adipose tissue represent an important defect in the insulin action (Rothman et al. 1995).

In insulin-responsive tissues such as skeletal muscle, adipose tissue and liver, the action of insulin is initiated by binding to its specific receptor. The insulin receptor is heterotetramer, consisting of two extracellular $\alpha$ subunits (binding fraction) and two transmembrane $\beta$ subunits (with intrinsic tyrosine kinase), linked by disulfide bonds (Draznin 2006). The activation of the insulin receptor provides a structural change in $\alpha$ subunit leading to autophosphorylation of a tyrosine kinase domain of $\beta$ subunits (White and Kahn 1994) and subsequent tyrosine phosphorylation of several protein intermediates, including insulin receptor substrate (IRS -1, 2, 3 and 4). Both of these phosphorylated 
substrates recognize and bind to domains with homology SH2, especially phosphatidylinositol3-kinase (PI3-K) (Backer et al. 1992, White and Kahn 1994). This enzyme is a dimer composed of a regulatory subunit (P 85) with two $\mathrm{SH} 2$ domains and one $\mathrm{SH} 3$ domain associated with a catalytic subunit ( $\mathrm{P}$ 110). The PI3-K is activated when phosphorylated IRS-1 binds to the SH2 domain, thereby activating its catalytic subunit (Backer et al. 1992, Cavalheira et al. 2002, White and Kahn 1994). The PI3-K promotes the catalysis of the inositol ring of phosphoinositides at position 3 resulting in $(3,4,5)$ phosphatidylinositol triphosphate (PIP3) from $(4,5)$ phosphatidylinositol biphosphate (Cavalheira et al. 2002, van Dam et al. 2005). PIP3 provides the phosphorylation of phosphoinositidedependent protein kinase 1 (PDK1) which in turn activates protein kinase $\mathrm{B}$ (PKB) or AKT (Kohn et al. 1998) and protein kinase C (PKC) (Shepherd and Kahn 1999). Following its recruitment to the cell surface, AKT is activated resulting in the AKTdependent phosphorylation of many substrates. The connector enhancer of KSR-1 protein (CNK1) was recently implicated in positive regulating insulin signaling through IRS-1 and PI3-K by being part of a complex via that indirectly stimulates the activity of phosphatidylinositol-4-phosphate 5-kinases at the plasma membrane to generate a $(4,5)$ biphosphate-rich microenvironment that is critical for the membrane recruitment of IRS- 1 and for the signaling to the PI3-K/AKT cascade (Lim et al. 2010). In adipose and muscle, finally, these kinases stimulate translocation of GLUT4 to the plasma membrane, facilitating the entry of glucose into the intracellular (van Dam et al. 2005) (Figure 1). In addition to glucose uptake, virtually all of insulin's metabolic effects are regulated by AKT. For example, AKT-dependent phosphorylation of glycogen synthase kinase 3 (GSK-3 $\beta$ ) leads to the activation of glycogen synthase and enhances glucose storage as glycogen (Rowland et al. 2011, Bouskila et al. 2010). The activation of AKT's kinase activity requires three steps, however, the order of these phosphorylation events is not clear yet (Rowland

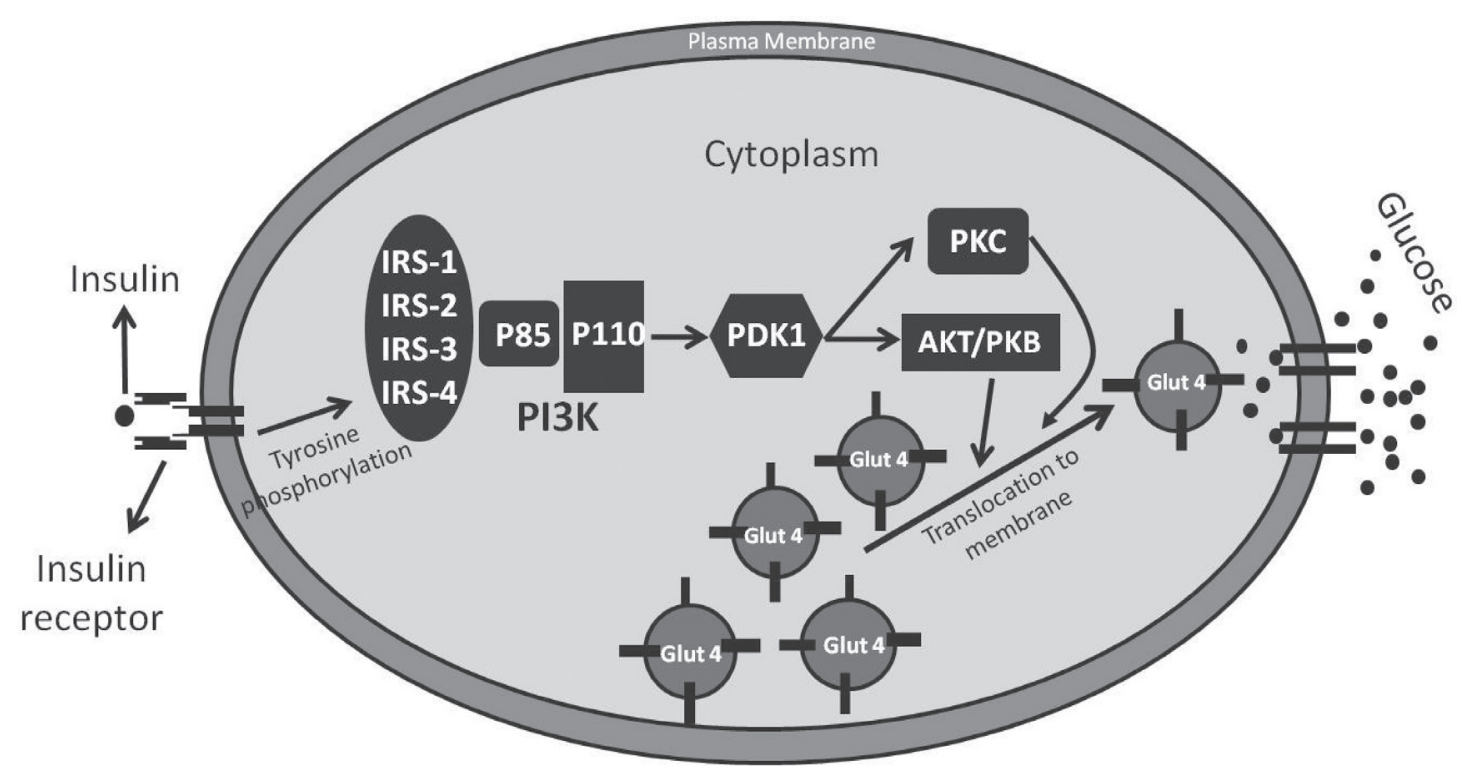

Figure 1 - The insulin activates a number of intracellular signaling proteins that are involved in the insulin-dependent glucose uptake mechanism [e.g., insulin receptor substrate (IRS), phosphatidylinositol-3-kinase (PI3K), regulatory subunit of PI3K (P85), catalytic subunit of PI3K (P110), phosphoinositide-dependent protein kinase 1(PDK1), protein kinase $\mathrm{C}$ (PKC), protein kinase $\mathrm{B}$ (PKB or AKT), and glucose transporters 4 (GLUT4)]. 
et al. 2011). The first one is the translocation to the plasma membrane and binding of PIP3. Secondly, the binding of PIP3 induces a conformational change in AKT, which is thought to be a necessary step prior to its phosphorylation at $\mathrm{Thr}^{308}$ by PDK1 and phosphorylation of $\mathrm{Thr}^{308}$ by PDK-1 leading to conformational change in the activation loop and exposure of the active site and, consequently, allowing the binding of both adenosine triphosphate (ATP) and the substrate protein (Milburn et al. 2003). Finally, phosphorylation of $\mathrm{Ser}^{473}$ probably by the mTORC2 complex also seems to be important. $\mathrm{Ser}^{473}$ is a regulatory phosphorylation site which is present in the C-terminal hydrophobic domain of AKT. Various candidate molecules working as kinase that phosphorylates $\operatorname{Ser}^{473}$ have been suggested, including protein kinase $\mathrm{C} \alpha(\mathrm{PKC} \alpha)$, the integrin-linked kinase, ATM, DNA-PK and autophosphorylation by AKT itself (Dong and Liu 2005). However, the mammalian target of rapamycin (mTOR) in complex with mLST8, mSin and rictor (the mTORC2 complex) has emerged as the strongest candidate for the $\mathrm{Ser}^{473}$ kinase (Sarbassov et al. 2005). Phosphorylation of $\operatorname{Ser}^{473}$ has been believed to play a dual role in the activation of AKT, acting as an anchorage site for PDK-1 in other AGC family kinases and as an allosteric regulator of AKT activity (Frodin et al. 2002).

\section{INSULIN-INDEPENDENT PATHWAY}

\section{AMP-activated protein kinase (AMPK)}

The AMPK protein complex is a family member of protein kinases composed of 12 molecules consisting of subunits $\alpha, \beta$ and $\gamma$ (Hardie et al. 2003, Musi and Goodyear 2003). Each $\alpha$ and $\beta$ subunit has two isoforms ( $\alpha 1$ and $\alpha 2$ or $\beta 1$ and $\beta 2$ ), whereas the $\gamma$ subunit has three isoforms $(\gamma 1, \gamma 2$ and $\gamma 3)$. The $\alpha$-subunit has catalytic activity, and $\beta$ and $\gamma$ subunits are important in substrate specificity and in maintaining the stability of heterotrimer (Jensen et al. 2008, Jessen and Goodyear 2005). AMPK plays a pivotal role in the glucose uptake, independent of insulin in myocytes. It is stimulated by the contraction of skeletal muscle and is activated by an increase in the AMP:ATP ratio and a decreased in the creatine:phosphocreatine ratio (Chen et al. 2000, Fujii et al. 2000, Winder and Hardie 1996, Wojtaszewski et al. 2003).

The muscle contractile activity alters the cellular energy state resulting in an increase in body metabolic requirement which triggers pathways that consume ATP with consequent increase in the concentration of byproducts, such as AMP (Hardie 2003, Kemp et al. 2003). Increases in levels of AMP activate AMPK allosterically, inducing phosphorylation of threonine residue ( $\mathrm{Thr}^{172}$ ) located in the catalytic $\alpha$-subunit by LKBI (upstream serine-threonine kinase) (Hardie et al. 2003, Kemp et al. 2003, Musi and Goodyear 2003). Therefore, physiological activation of AMPK occurs during contraction/exercise likely in response to increased binding of AMP and ADP and decreased binding of ATP to the $\gamma$-subunit (Richter and Hargreaves 2012).

Recent evidence supports the role of AMPK in cell signaling for the glucose transport by means of 5-aminoimidazole-4carboxamide-1- $\beta$ D-ribonucleoside (AICAR) (Fisher et al. 2005, Ju et al. 2007, Wijesekara et al. 2006). The AICAR mimics the effect of AMP on AMPK. In fact, studies in vitro showed that isolated rat muscles, and both healthy and T2D human muscles exposed to AICAR, exhibited an increase on glucose transport in the absence of insulin (Bergeron et al. 1999, Hayashi et al. 1998, Koistinen et al. 2003, Miyamoto et al. 2007). In addition, the combination of AICAR and insulin promoted an additional glucose transport in muscle and neuronal cells (Shah et al. 2011, Fediuc et al. 2006, Hayashi et al. 1998). However, the effect of AICAR on glucose uptake is lost when $\alpha 2$ or $\gamma 3$ AMPK subunits are deficient (Barnes et al. 2004, Jorgensen et al. 2004, Mu et al. 2001). 
The pathways of glucose uptake induced by both muscle contraction and AICAR appear to be distinct. Jorgensen et al. 2004, studying soleus and EDL muscles of mice, showed that muscles of $\alpha 1$ or a2-AMPK knockout (KO) mice when stimulated by muscle contraction, present glucose uptake similar to wild-type mice. However, when stimulated by AICAR, only muscles of a1-AMPK KO mice showed glucose uptake levels preserved. Thus, it can be suggested that AICAR-stimulated glucose uptake is dependent of $\alpha 2$-AMPK subunit. Corroborating with these data, Fujii et al. 2005, studying transgenic mice carrying cDNAs of inactivity $\alpha 2$-catalytic subunits of AMPK, showed that AICAR-stimulated glucose transport was fully inhibited. However, the lack of AMPK $\alpha 2$-activity had no effect on contraction-induced glucose transport.

Lastly, AMPK proves to be an important exercise/contraction-stimulated glucose uptake pathway, mainly, by increased AMP and ADP levels.

\section{Calcium}

The repeated contraction of skeletal muscle can provide an increase in myocyte calcium concentrations (Chin 2005, Jessen and Goodyear 2005). This increase has been implicated in GLUT4 translocation and glucose transport (Jessen and Goodyear 2005, Kurth-Kraczek et al. 1999). In addition, calcium stimulates glucose transport in skeletal muscle by pathways, independent of contraction (Youn et al. 1991). The supposed mechanisms by which calcium can stimulate glucose uptake are not fully understood. Potential candidates include calmodulin-protein kinase and protein kinase C (PKC) (Chin 2005, Richter et al. 2001, 2004, Wheatley et al. 2004). The interaction of calciumcalmodulin kinase (CaMK) proved to be an additional mechanism for the activation of AMPK via Thr ${ }^{172}$ phosphorylation, as well as for promoting other possible effects to initiate the GLUT4 translocation (Jensen et al. 2007b, Ojuka 2004, Ojuka et al. 2002, Wijesekara et al. 2006, Wright et al. 2004, 2005).
Evidence showed that caffeine stimulates an increase in intracellular calcium levels in isolated rat muscles with consequent increase in glucose uptake independent of muscle contraction (Terada et al. 2003). In addition, several studies showed that incubation with caffeine increase nucleotide turnover and AMPK activation in muscle from mice and rats independently of muscle contraction (Egawa et al. , Jensen et al. 2007a, Richter and Hargreaves) probably due to the relevant energy demand posed by sarcoplasmatic reticulum $\mathrm{Ca}^{2+}$-ATPase-dependent $\mathrm{Ca}^{2+}$ (SERCA) reuptake (Norris et al. 2012, Richter and Hargreaves). Thus, these studies suggested that the increase in glucose uptake is due to metabolic stress triggered by SERCA activation and muscle contraction and not by direct action of calcium.

Nitric oxide (NO)

$\mathrm{NO}$ is an endogenous signaling molecule, involved in the regulation of several physiological functions as well as in mediation of a variety of pathophysiological processes (Moncada and Higgs 1993). In addition to its physiological implications in the cardiovascular system (vasodilatation, for example), it has recently been postulated that NO has an important role in glucose uptake by skeletal muscle (Merry et al. 2010a). Studies with animals and humans supported the hypothesis that the glucose uptake pathway stimulated by NO may be independent of both insulin and muscle contraction (Higaki et al. 2001, Henstridge et al. 2009). However, other evidence have shown the importance of proper functioning of this system to optimize the insulin-dependent uptake of glucose (Roy et al. 1998). In humans, inhibition of NO by L-NMMMA decreased glucose uptake in type 2 diabetics and healthy patients without affecting total blood flow (Bradley et al. 1999). Despite the contributions previously reported, some assays have shown that NO plays a role in glucose metabolism independently of insulin pathway. Even after the pharmacological inhibition of PI3K, glucose uptake 
stimulated by NO is still preserved (Tanaka et al. 2003). Regarding the participation of NO in glucose uptake stimulated by muscle contraction, studies are inconclusive, although some evidence has indicated that inhibition of NO blocks glucose uptake stimulated by muscle contraction (Roberts et al. 1997). However, other studies using simultaneously either muscle contraction or exogenous mechanisms that stimulate AMPK and an inhibitor of NO, have shown that glucose transport remains normal (Etgen et al. 1997, Higaki et al. 2001). These data suggest that the mechanisms involved in glucose uptake mediated by NO signaling pathways may be distinct from both insulin and muscle contraction pathways. Another interesting finding is the influence of muscle fiber type in glucose uptake mediated by NO. A study with animals demonstrated that inhibition of NO reduces contraction-induced glucose uptake, only in fast twitch muscles (Merry et al. 2010b).

\section{Bradykinin}

Bradykinin is a nonapeptide hormone that mediates important physiological effects such as inflammation, vascular permeability, hypotension, edema, smooth muscle contraction and glucose metabolism (Kishi et al. 1998), and most of these actions is mediated by the B2R receptor (Dumke et al. 2002). Studies have shown that bradykinin influences glucose metabolism through both insulindependent and insulin-independent pathways (Motoshima et al. 2000). It has been shown that the administration of bradykinin increases glucose uptake in cultured adipocytes and skeletal muscles of the forearm in humans (Duka et al. 2001). In addition, bradykinin reduces hyperinsulinemia, decreases the concentration of plasma free fatty acids, improves glucose tolerance, increases insulin action in target tissues (Henriksen et al. 1998) and enhances glucose transport through exercise (insulin-independent pathway) (Kishi et al. 1998). Furthermore, a relationship between bradykinin and other mechanisms of glucose uptake has been proposed as evidenced for the increased glucose uptake after intra-hypothalamic infusion of leptin (Shiuchi et al. 2001).

Some mechanisms have been proposed to explain how bradykinin interferes in the glucose metabolism. Studies have reported that bradykinin enhances the tyrosine phosphorylation of IRS-1 and thus improves the binding affinity of IRS- 1 with the P85 regulatory subunit of PI3K, which increases the translocation of GLUT4 to the plasma membrane. Therefore, the insulin-dependent glucose uptake is improved (Motoshima et al. 2000). Additionally, it has been postulated that the use of angiotensinconverting enzyme (ACE) inhibitors reduces insulin resistance and diabetes risk (Al-Mallah et al. 2010). Some studies have also observed that the ACE inhibitors lead to an increase in glucose uptake in murine skeletal muscle due to increased bioavailability of bradykinin caused by this drug (Shiuchi et al. 2002). However, some mechanisms are still unclear and further investigations are needed in this field.

Reactive Oxygen Species (ROS)

ROS are reactive molecules that have an unpaired electron in their outer layer. Chronic high levels of ROS are associated with the pathophysiology of numerous diseases including diabetes and cardiovascular disease (Powers and Jackson 2008). However, current studies have suggested that physiological levels of ROS, especially of hydrogen peroxide $\left(\mathrm{H}_{2} \mathrm{O}_{2}\right)$, may act as signaling molecules in the regulation of gene expression and cellular metabolism (Jackson 2008, Ji 2008, Katz 2007). In skeletal muscle, the production of ROS may be promoted by various stimuli, including hypoxia, insulin and muscle contraction (Merry and McConell).

Relevant evidences demonstrated the ability of exogenous $\mathrm{H}_{2} \mathrm{O}_{2}$ to stimulate basal glucose uptake in isolated skeletal muscle (Cartee and Holloszy 1990). Corroborating with previous findings, Sandstrom 
et al. (Sandstrom et al. 2006) demonstrated that treatment with the N-acetylcysteine (NAC) and ebselen antioxidants reduced the elevation in ROS by contraction and attenuated glucose uptake. In the meantime, studies on human have shown that infusion of NAC did not decrease exercisestimulated glucose uptake (Merry et al. 2010b).

There is evidence that ROS produced during contraction of skeletal muscle play a role in the regulation of glucose uptake (Merry and McConell 2012). However, the molecular mechanisms by which ROS may regulate glucose uptake in skeletal muscle are still unclear. Sandstrom et al (Sandstrom et al. 2006) demonstrated that the antioxidant NAC attenuated AMPK activity and reduced contractionstimulated glucose uptake in skeletal muscle. However, Merry et al. 2010c investigated glucose uptake in skeletal muscle from AMPK kinase knockout and wild-type mice and showed that the NAC antioxidant similarly inhibited contractionstimulated glucose uptake. Thus, they suggested that ROS could regulate glucose uptake in skeletal muscle by AMPK independent pathway. In addition, some studies have shown a possible interaction of ROS in the calcium (Merry et al. 2012) and NO (Erickson and Anderson 2008) signaling pathways. However, due to controversial results presented so far, it becomes necessary to conduct new studies.

Convergent mechanisms of glucose uptake: role of $A S 160$ and TBC1D1

It is generally believed that insulin stimulates GLUT4 translocation by molecular mechanisms distinct from contraction pathway (Goodyear et al. 1990, Lee et al. 1995, Lund et al. 1995). However, these two pathways at least partially converge in distal parts. Therefore, there are some signaling molecules related to GLUT4 translocation that are activated by both insulin and muscle contraction, and possibly the most important are the Akt substrate of $160 \mathrm{kDa}(\mathrm{AS} 160)$ and TBC1D1. AS160 is a Rab GTPase-activating protein (GAP) that modulates GLUT4 trafficking in insulin-sensitive 3T3-L1 adipocytes and L6 myoblasts (Kramer et al. 2006). Under basal conditions, AS160 exists primarily in an unphosphorylated state and retains GLUT4 vesicles intracellular. When cells are treated with insulin, AS160 is rapidly phosphorylated at multiple Akt phospho-motifs (Kane et al. 2002). When 3T3-L1 adipocytes and L6 GLUT4-myc myoblasts were transfected with a constitutively active mutant AS160 (incapable of being phosphorylated at these regulatory sites), a significantly reduced insulin-induced GLUT4 translocation was observed (Sano et al. 2003, Thong et al. 2005). In addition, previous studies have reported increased AS160 phosphorylation with in vitro contractions in rat epitrochlearis muscles (Bruss et al. 2005). This suggests that AS160 operates as a common, downstream point of convergence between insulin-mediated and muscle contraction pathways Kramer et al. 2006, using AMPK $\alpha 2$-inactive transgenic mice, observed that AICAR-stimulated AS160 phosphorylation was fully inhibited, whereas contraction-stimulated AS160 phosphorylation was partially reduced in the mice and the combined AMPK $\alpha 2$ and Akt inhibition by wortmannin treatment of AMPK $\alpha 2$ transgenic mice, did not fully ablate contraction-stimulated AS160 phosphorylation. However, insulin, together with either AICAR or contraction, increased AS160 phosphorylation in an additive manner, indicating that AS160 is a point of convergence linking insulin, contraction, and AICAR signaling. On the other hand, Taylor et al. observed a dissociation between AS160 protein expression and apparent AS160 PAS phosphorylation among types of muscles and identified the AS160 paralog protein TBC1D1 (Taylor et al. 2008). They also observed an increased TBC1D1 phosphorylation in vivo stimulated by insulin, contraction, and the AMP-activated protein kinase (AMPK) activator AICAR. Other studies confirmed the role of 
TBC1D1 in regulation of glucose metabolism in skeletal muscle in response to contraction and insulin stimuli (An et al. 2010, Pehmoller et al. 2009, Szekeres et al. 2012).

\section{ROLE OF PHYSICAL EXERCISE, DIET, AND PHARMACOLOGICAL AGENTS ON THE GLUCOSE UPTAKE PATHWAYS}

Physical EXercise AND Glucose Uptake

Several studies have reported benefits of physical training and muscle contraction in the treatment and prevention of T2D, due to optimization of glucose uptake by insulin-dependent and independent pathways (Hayashi et al. 1997, Heinonen et al. 2012). Regarding the effects of exercise on insulin dependent pathway, it proved to be effective in improving insulin action in skeletal muscle of insulin-resistant and diabetic patients (Eriksson 1999). However, it is noteworthy that physical training contributes differently to glucose uptake in different tissues such as skeletal muscle and adipose tissue (Reichkendler et al. 2013). Many of the beneficial actions of exercise on glucose transport mediated by insulin is due to the increased GLUT-4 protein expression (Goodyear et al. 1992) and a better adaptation of enzymes involved in glucose phosphorylation and oxidation (Holloszy and Hansen 1996, Ivy et al. 1999).

Considering the important role of proteins of the insulin-dependent glucose uptake pathway, numerous studies have been conducted to clarify the role of exercise on the activity and expression of these proteins. In rodents, King et al. 1993 demonstrated that the exercise-induced translocation of the GLUT-4 in obese Zucker rats were similar to lean animals. Other studies have shown that physical training leads to the phosphorylation of insulin receptor tyrosine and enhance IRS-1 protein expression (Hevener et al. 2000). However, there was no change in protein expression of insulin receptor $\beta$-subunit, p85 subunit of PI3-K and AKT/
PKB (Hevener et al. 2000). It is noteworthy that physical training decreasing inflammatory markers as tumor necrosis factor $\alpha$ (Sheibani et al. 2012, Kirwan and del Aguila 2003), C-reactive protein (Jorge et al. 2011, Kadoglou et al. 2007) and interleukin-18 (Kadoglou et al. 2007) in skeletal muscle and body fat mass (Sheibani et al. 2012, Kadoglou et al. 2007). This effect is important to increase expression of GLUT-4 (Kirwan and del Aguila 2003), IRS-1 (Jorge et al. 2011) and insulin sensitivity (Kirwan and del Aguila 2003). Beyond the direct benefits in the insulin-dependent glucose uptake pathway, physical training increases maximal aerobic capacity (Cortez et al. 1991), and raises the levels of enzymes involved in glucose catabolism (hexokinase and citrate synthase) (Banks et al. 1992, Brozinick et al. 1993, Cortez et al. 1991).

Cusi et al. (2000), studying patients with T2D, demonstrated that 24 hours after a single exercise session (Cycle Ergometer $1 \mathrm{~h}$ of exercise at $65 \%$ of VO2max) there was an increase in tyrosine phosphorylation of the insulin receptor and IRS1 in skeletal muscle. However, the activity of PI3-K associated with IRS-1 was not elevated after exercise. Additionally, Jorge et al.2011, studying the role of resistance, aerobic and combined training in glycemic control of patients with T2D, showed that both types of training were effective in improving glycemic control. Furthermore, resistance training increased at $90 \%$ the IRS-1 expression. Some studies have demonstrated the role of chronic hypoxia on glucose metabolism (Gamboa et al.). Mackenzie et al. 2012, also studying patients with T2D, showed that intermittent exercise during moderate hypoxia presented better results in insulin resistance index and glucose disposal when compared with the same intensity exercise performed in normoxia.

Therefore, as shown in above studies, exercise can provide direct and indirect benefits for insulin resistant and diabetic patients. However, further studies are needed to clarify and reveal new therapeutic mechanisms associated with physical exercise. 
Regarding the effects of exercise on insulin independent pathway, exercise plays an important role in insulin-independent glucose uptake (Santos et al. 2008). During exercise there is an overactivation of the sympathetic nervous system, resulting in increased catecholamines levels, which are responsible for inhibiting the secretion of insulin and stimulating the secretion of glucagon from the pancreas. Furthermore, there is an increase in cortisol levels which are known to enhance insulin resistance (McMurray and Hackney 2005).

Most studies that investigated the insulinindependent glucose uptake mechanisms were performed in vitro and used the muscle contraction to induce activation of several pathways (Santos et al. 2008). However, there is consensus that the most simple and effective way to stimulate systemic muscle contraction is through physical exercise.
Therefore, all the benefits demonstrated by muscle contraction in insulin-independent glucose uptake can be extrapolated to an exercise session.

As shown previously, many biological pathways have played an important role in insulin-independent glucose uptake mechanisms (Santos et al. 2008). The main pathways investigated regarding the impact of muscle contraction/exercise on insulin-independent glucose uptake are: AMPK, NO, ROS, AKT, calcium, bradykinin (Figure 2).

\section{DIET AND GLUCOSE UPTAKE}

AMPK is activated by metabolic stresses that either inhibit ATP production (e.g. hypoglycaemia) or accelerate ATP consumption (e.g. muscle contraction). Once activated, it switches on catabolic pathways that generate ATP, while switching off biosynthetic pathways and other processes that

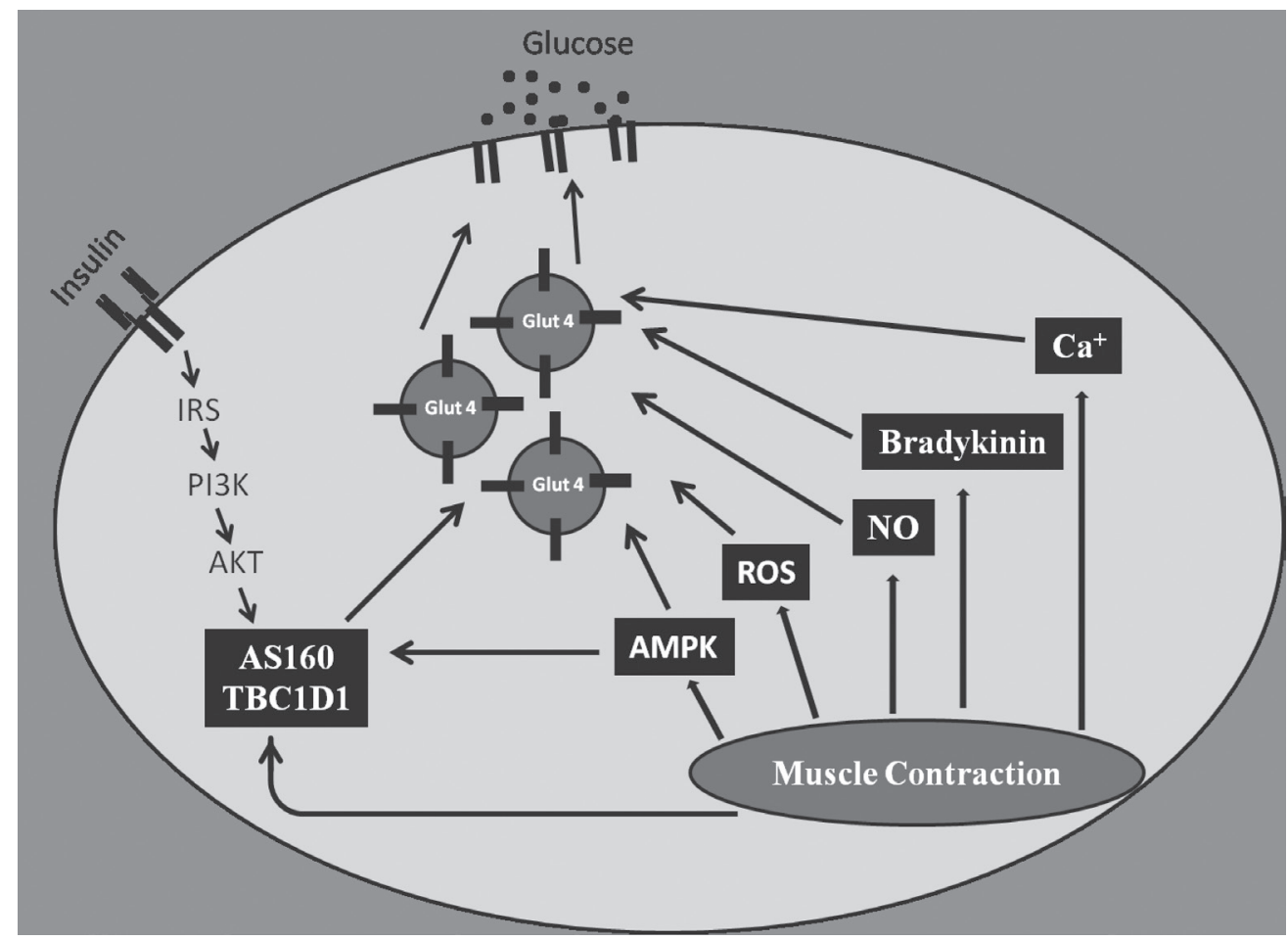

Figure 2 - Muscle contractions cause translocation of the glucose transporter proteins (GLUT4) to the cell membrane. Contraction activates a number of signaling proteins that might be involved in the exercise signaling mechanism [e.g., AMP-activated protein kinase (AMPK), calcium, nitric oxide (NO), bradykinin, Akt substrate of $160 \mathrm{kDa}(\mathrm{AS} 160)$, TBC1D1 and reactive oxygen species (ROS)]. 
consume ATP. Its key roles in maintaining energy balance suggest that it would also be an important player in the derangements of energy metabolism that occur in conditions like obesity, metabolic syndrome and T2D (Hardie and Sakamoto 2006). Developed and developing countries underwent or are undergoing fast nutrition transition from a healthy traditional high-fiber, low-fat, low-calorie diet, toward increasing consumption of caloriedense foods containing refined carbohydrates, fats, red meats, and low fiber. In addition, a decreased levels of exercise in the general population lead to increases in obesity, the metabolic syndrome and T2D. The metabolic syndrome involves a set of risk factors for cardiovascular disease such as insulin resistance, hypertension, altered plasma lipids (mainly hypertriglyceridemia and low highdensity lipoprotein cholesterol), and abdominal obesity (Hardie 2008, Misra et al. 2010). Risk of developing T2D is greatly increased by metabolic syndrome, which appears to orchestrate the adaptive physiology of energy deficit, suggesting that the sedentary modern human could be suffering from chronic suboptimal AMPK activation (Mor and Unnikrishnan 2011).

Regarding the glucose uptake insulin-dependent pathway, the nutrient availability, growth factors as well as energy metabolism and stress, all regulate mTOR activity, which plays an important role both in insulin signaling and in the regulation of cellular function in response to nutritional modifications (Matsakas and Patel 2009, Rennie 2007). On the other hand, glucose deprivation is able to lead activation of AMPK in cultured mammalian cells (Salt et al. 1998); however, regulation of AMPK by glucose in vivo may be normally restricted to specialized cells, including pancreatic $\beta$-cells and hypothalamus cells, of which the latter is the inhibitor of feeding behavior in response to hypoglycemia (Kang et al. 2006). In this scenario, the rate of glucose metabolism responds to physiological fluctuations in blood glucose and there is evidence that AMPK activity correlates inversely with glucose over a physiologically relevant concentration range (Hardie and Sakamoto 2006, Minokoshi et al. 2004).

Lastly, AMPK activation has potential to lower plasma glucose by repressing expression of enzymes of gluconeogenesis in the liver and by increasing glucose uptake by muscle and other tissues. Also, to reduce hypertriglyceridemia, as well as elevated storage of triglycerides in muscle and liver by inhibiting fatty acid and triglyceride synthesis and stimulating fatty acid oxidation and mitochondrial biogenesis (Hardie 2008). In this field, Musi et al reported that novel AMPK-specific compounds are allowing researchers to examine whether this enzyme is a useful pharmacologic target for the treatment of human disease and whether chronic activation of AMPK will be safe (Sriwijitkamol and Musi 2008, Li et al. 2012).

HYPOGLYCEMIC DRUGS AND GLUCOSE UPTAKE

T2D is a prevalent metabolic disorder characterized by elevated blood glucose levels (hyperglycemia). Currently, there are several pharmacological interventions available for treating this condition. With regards to type 1 diabetes mellitus, the main intervention is the subcutaneous administration of insulin (Krentz and Bailey 2005). On the other hand, the use of insulin in T2D is only necessary in some cases (Guillausseau et al. 2008), and the treatments frequently used are oral hypoglycemic drugs, which are drugs that act either on pancreatic $\beta$-cells increasing insulin secretion (sulphonylureas or metaglinides) or medications for the improvement of peripheral sensitivity to insulin (biguanides and thiazolidinediones). In addition to these classes of drugs, there are also agents that inhibit intestinal $\alpha$-glucosidase (Krentz and Bailey 2005), which are able to reduce postprandial hyperglycemia and they modulate the intestinal system of incretins, either by increasing endogenous glucagon-like peptide-1 
(GLP-1, dipeptidyl peptidase-4 inhibitors) or by mimicking the action of GLP-1 (GLP-1 agonists) (Drucker et al. 2011). Here, we emphasize the biguanides (metformin) and PPAR $\gamma$ agonists (thiazolidinediones or glitazones).

Metformin is considered the main oral hypoglycemic agent used in the treatment of T2D due to its characteristics of action, efficacy and safety (Bennett et al. 2012). The main effect of this drug is to acutely decrease hepatic glucose production, mostly through a mild and transient inhibition of the mitochondrial respiratory chain complex I (Krentz and Bailey 2005, Viollet et al. 2012). The molecular mechanisms of action of metformin are not fully understood, but some studies have demonstrated a close relationship between the metformin and the activity of some enzymes involved in carbohydrate metabolism, such as AMPK (Musi et al. 2002). The resulting decrease in hepatic energy status activates AMPK, a cellular metabolic sensor, providing a generally accepted mechanism for the action of metformin on hepatic gluconeogenesis. Respiratory chain complex I, but not AMPK, is the primary target of metformin. This was strengthened by showing that the metabolic effect of the drug is preserved in liver-specific AMPK-deficient mice (Viollet et al. 2012). It is worth remembering that AMPK inhibits gluconeogenesis and glycogenolysis, stimulates glycogenesis in hepatocytes, and increases glucose uptake in peripheral tissues (Zang et al. 2004, Zhou et al. 2001). Besides the effects on the liver and skeletal muscle, studies have shown that metformin activates AMPK in aortic endothelial tissue in vivo (Zou et al. 2004). Therefore, it can be stated that some of the mechanisms of action of metformin may be explained by AMPK activation (Schultze et al. 2012, Viollet et al. 2012).

Metformin is also able to reduce the progression of states of pre-diabetes, as it was observed in the Diabetes Prevention Program trial (Knowler et al. 2002). Beyond its effect on glucose metabolism, metformin has been reported to restore ovarian function in PCOS (polycystic ovary syndrome), to reduce fatty liver, and to lower microvascular and macrovascular complications associated with T2D. Its use has also been suggested as an adjuvant treatment for cancer or gestational diabetes (Aldea et al. 2011, Belda-Iniesta et al. 2011).

Treatment with the first clinically approved thiazolidinediones (TZDs), troglitazone, was withdrawn from the market because of cases of severe liver toxicity, but rosiglitazone and pioglitazone entered the market in the 1990s. In 2010, the United States FDA (Food and Drug Administration) and other agencies restricted the use of both rosiglitazone and pioglitazone, and the European Medicines Agency even recommended suspension of the marketing authorization for rosiglitazone giving its cardiovascular risk profile (Phielix et al. 2011). The mechanism of action of TZDs involves the binding to nuclear receptors $\operatorname{PPAR} \gamma$ (peroxisome-proliferator-activated receptors type gamma). After binding, there is a conformational change in the receptor, which allows the connection with the retinoic acid receptor (RXR) and recruitment of one or more co-activators. The interaction of this complex heterodimer with the nuclear regions determines responsive transcription of approximately 500 genes, some of which are closely related to lipid metabolism, glucose and cell differentiation (Owen et al. 2000). Corroborating with these possible mechanisms, studies have shown an improvement in insulin sensitivity in muscle, liver and adipose tissue when individuals are treated with glitazones for 3 months (Abrahamson 2003), which demonstrates the therapeutic potential of these drugs in the treatment of T2D. The TZDs act mainly by improving peripheral uptake and utilization of glucose in muscle and adipose tissue. However, the mechanisms by which glitazones increase the uptake of glucose are not fully understood. In vitro studies showed that cultured cells in the presence 
of troglitazone become insulin responsive, with an absolute rate of insulin-stimulated glucose uptake increase under these conditions (troglitazone)(Hamm et al. 1999). In vivo study that used euglycemic hyperinsulinemic clamp combined with an oral glucose load before and after 3-month treatment with pioglitazone or placebo, reported that pioglitazone is effective for ameliorating insulin resistance in T2D subjects by enhancing splanchnic glucose uptake as well as peripheral glucose uptake (Kawamori et al. 1998). These data were corroborated by a systematic review (Natali and Ferrannini 2006). In addition, thiazolidinediones could improve synergic action of insulin and exercise. Hällsten et al found that rosiglitazone (but not metformin) improved insulin responsiveness in resting skeletal muscle and doubled the insulin-stimulated glucose uptake rate during physical exercise in patients with newly diagnosed T2D (Hallsten et al. 2002). A common mechanism that may explain much of the influence of TZDs on glucose uptake could be through the AMPK pathway. AMPK has been implicated in the insulin-sensitizing actions of TZDs: a study has revealed the influence of intravenous infusion of the AMPK activator 5-aminoimidazole 4-carboxamide riboside (AICAR) under euglycemic and iso-insulinemic conditions in insulin-resistant high-fat-fed rats. The authors found that rosiglitazone treatment significantly enhanced AICAR-stimulated whole-body glucose disposal by $27 \%$ and a $44 \%$ greater glucose infusion rate was required to maintain euglycemia (Ye et al. 2006). Both AICAR-stimulated glucose uptake and glucose incorporation into glycogen in muscle and adipose tissue were enhanced. Finally, the enhanced glucose uptake and glycogen synthesis in muscle were associated with increased activity of total AMPK and the AMPKalpha2 subunit (Ye et al. 2006). In this context, therapy with glitazones have beneficial effects on glycemic control; however, some of the adverse effects such as weight gain, edema, heart failure, anemia, hepatotoxicity, and others (Nissen and Wolski 2007) may limit the use of TZDs.

\section{CONCLUSION}

With a better understanding about these pathways, it is possible to evaluate, exactly and molecularly, the importance of physical exercise and diet on glucose homeostasis. Furthermore, to test the action of drugs that might optimize glucose uptake and consequently be an important step in controlling blood glucose levels in diabetic patients. There is no potential conflict of interest.

\section{RESUMO}

A captação de glicose nos tecidos periféricos é dependente da translocação dos transportadores de glicose GLUT4 para a membrana plasmática. Estudos mostram a existência de duas principais vias de sinalização que induzem à translocação do GLUT4. A primeira e amplamente investigada é a via de sinalização ativada pela insulina por meio do substrato 1 do receptor de insulina e fosfatidilinositol-3-quinase. A segunda é a via de sinalização independente da insulina que é ativada, principalmente, pela contração muscular. Indivíduos com diabetes mellitus tipo 2 apresentam uma redução na captação de glicose estimulada pela insulina devido à resistência insulínica. Contudo, esses indivíduos geralmente apresentam captação de glicose normal durante o exercício. Neste contexto, o exercício físico é, reconhecidamente, uma das intervenções mais importantes na estimulação da captação de glicose por vias insulino-independentes, cujas principais moléculas envolvidas são: proteína quinase ativada por adenosina monofosfato, óxido nítrico, bradicinina, AKT, espécies reativas de oxigênio e cálcio. Nesta revisão, os objetivos são: destacar as particularidades das diferentes vias de captação de glicose e relatar os efeitos do exercício físico, da dieta e de medicamentos sobre o funcionamento das mesmas. Também, entender molecularmente a importância do exercício físico e da dieta na homeostase glicêmica e, avaliar à ação de fármacos que melhoram a captação de glicose, o que é um importante ponto na eficácia 
do controle glicêmico de pacientes diabéticos, bem como esclarecer alguns mecanismos que justificam o desenvolvimento de novos fármacos com fins de mimetizar a via contração muscular.

Palavras-chave: diabetes, exercício físico, absorção de glicose, dieta, fármacos hipoglicemiantes.

\section{REFERENCES}

ABRAHAMSON MJ. 2003. Clinical use of thiazolidinediones: recommendations. Am J Med 115 Suppl 8A: 116S-120S.

Aldeam, Tomuleasa C, Petrushev B, Susman S, Kacso GI, IrIMIE A, FLORIAN IS AND SORITAU O. 2011. Antidiabetic pharmacology: a link between metabolic syndrome and neuro-oncology? J BUON 16: 409-413.

al-Mallah M, Khawaja O, Sinno M, Alzohaili O AND SAMRA AB. 2010. Do angiotensin converting enzyme inhibitors or angiotensin receptor blockers prevent diabetes mellitus? A meta-analysis. Cardiol J 17: 448-456.

An D, TOYODA T, TAYLOR EB, YU H, FUJII N, HirSHMAN MF AND GOODYEAR LJ. 2010. TBC1D1 regulates insulin- and contraction-induced glucose transport in mouse skeletal muscle. Diabetes 59: 1358-1365.

BACKER JM ET AL. 1992. Phosphatidylinositol 3'-kinase is activated by association with IRS-1 during insulin stimulation. EMBO J 11: 3469-3479.

BANKS EA, BROZINICK Jr JT, YASPELKIS BB, 3RD, KANG HY AND Ivy JL. 1992. Muscle glucose transport, GLUT-4 content, and degree of exercise training in obese Zucker rats. Am J Physiol 263: E1010-1015.

BARNES BR ET AL. 2004. The 5'-AMP-activated protein kinase gamma3 isoform has a key role in carbohydrate and lipid metabolism in glycolytic skeletal muscle. J Biol Chem 279: 38441-38447.

Belda-Iniesta C, Pernia O AND Simo R. 2011. Metformin: a new option in cancer treatment. Clin Transl Oncol 13: 363-367.

BenNetT WL, Odelola OA, Wilson LM, Bolen S, Selvaraj S, Robinson KA, Bass EB and Puhan MA. 2012. Evaluation of guideline recommendations on oral medications for type 2 diabetes mellitus: a systematic review. Ann Intern Med 156: 27-36.

Bergeron R, Russell RR, 3RD, Young LH, Ren JM, MarcucCi M, Lee A AND ShUlman GI. 1999. Effect of AMPK activation on muscle glucose metabolism in conscious rats. Am J Physiol 276: E938-944.

Bouskila M, Hunter RW, IBRahim AF, Delattre L, PegGie M, VAN DiePEN JA, Voshol PJ, JENSEN J AND SAKAMOto K. 2010. Allosteric regulation of glycogen synthase controls glycogen synthesis in muscle. Cell Metab 12: 456-466.

BRADLEY SJ, KINGWELl BA AND MCCONELL GK. 1999. Nitric oxide synthase inhibition reduces leg glucose uptake but not blood flow during dynamic exercise in humans. Diabetes 48: 1815-1821.
BROZINICK Jr JT, ETGEN Jr GJ, YASPELKIS BB, 3RD, KANG HY AND IVY JL. 1993. Effects of exercise training on muscle GLUT-4 protein content and translocation in obese Zucker rats. Am J Physiol 265: E419-427.

BRUSS MD, ARIAS EB, LIENHARD GE AND CARTEE GD. 2005. Increased phosphorylation of Akt substrate of $160 \mathrm{kDa}$ (AS160) in rat skeletal muscle in response to insulin or contractile activity. Diabetes 54: 41-50.

CARTEE GD and Holloszy JO. 1990. Exercise increases susceptibility of muscle glucose transport to activation by various stimuli. Am J Physiol 258: E390-393.

CAVALHEIRA JBC, ZECCHIN HG AND SAAD MJA. 2002. Vias de sinalização da insulina. Arq Bras Endocrinol Metab 46: 419-425.

Chen ZP, McConell GK, Michell BJ, Snow RJ, Canny BJ AND KEMP BE. 2000. AMPK signaling in contracting human skeletal muscle: acetyl-CoA carboxylase and NO synthase phosphorylation. Am J Physiol Endocrinol Metab 279: E1202-1206.

CHIN ER. 2005. Role of Ca2+/calmodulin-dependent kinases in skeletal muscle plasticity. J Appl Physiol 99: 414-423.

CORTEZ MY, TORGAN CE, BROZINICK Jr JT, AND IVY JL. 1991. Insulin resistance of obese Zucker rats exercise trained at two different intensities. Am J Physiol 261: E613-619.

Cusi K, Maezono K, Osman A, Pendergrass M, Patti ME, Pratipanawatr T, Defronzo RA, KaHn CR AND MANDARINO LJ. 2000. Insulin resistance differentially affects the PI 3-kinase- and MAP kinase-mediated signaling in human muscle. J Clin Invest 105: 311-320.

Dela F, Larsen JJ, Mikines KJ, Ploug T, Petersen LN AND GaLBo H. 1995. Insulin-stimulated muscle glucose clearance in patients with NIDDM. Effects of one-legged physical training. Diabetes 44: 1010-1020.

DONG LQ AND LIU F. 2005. PDK2: the missing piece in the receptor tyrosine kinase signaling pathway puzzle. Am J Physiol Endocrinol Metab 289: E187-196.

DRAZNIN B. 2006. Molecular mechanisms of insulin resistance: serine phosphorylation of insulin receptor substrate- 1 and increased expression of p85alpha: the two sides of a coin. Diabetes 55: 2392-2397.

Drucker DJ, Sherman SI, Bergenstal RM AND Buse JB. 2011. The safety of incretin-based therapies-review of the scientific evidence. J Clin Endocrinol Metab 96: 2027-2031.

Duka I, Shenouda S, Johns C, KintSURAShVILI E, GaVRas I AND GAVRAS H. 2001. Role of the B(2) receptor of bradykinin in insulin sensitivity. Hypertension 38: 1355-1360.

DumKe CL, Kim J, ARIas EB AND CARTEE GD. 2002. Role of kallikrein-kininogen system in insulin-stimulated glucose transport after muscle contractions. J Appl Physiol 92: 657-664.

Egawa T, Hamada T, MA X, KaraiKe K, Kameda N, Masuda S, IWANAKA N AND HAYASHI T. 2011. Caffeine activates preferentially alpha1-isoform of 5'AMP-activated protein kinase in rat skeletal muscle. Acta Physiol (Oxf) 201: 227-238.

ERICKSON Jr AND ANDERSON ME. 2008. CaMKII and its role in cardiac arrhythmia. J Cardiovasc Electrophysiol 19: 1332-1336. 
ERIKSSON JG. 1999. Exercise and the treatment of type 2 diabetes mellitus. An update. Sports Med 27: 381-391.

ETGEN Jr GJ, FrYBURG DA AND GIBBS EM. 1997. Nitric oxide stimulates skeletal muscle glucose transport through a calcium/contraction- and phosphatidylinositol-3-kinaseindependent pathway. Diabetes 46: 1915-1919.

FedIUC S, GAIDHU MP AND CEDDIA RB. 2006. Inhibition of insulin-stimulated glycogen synthesis by 5 -aminoimidasole4-carboxamide-1-beta-d-ribofuranoside-induced adenosine 5'-monophosphate-activated protein kinase activation: interactions with Akt, glycogen synthase kinase 3-3alpha/ beta, and glycogen synthase in isolated rat soleus muscle. Endocrinology 147: 5170-5177.

Fisher JS, Ju JS, OPPELT PJ, SMith JL, SUZUKi A AND ESUMI H. 2005. Muscle contractions, AICAR, and insulin cause phosphorylation of an AMPK-related kinase. Am J Physiol Endocrinol Metab 289: E986-992.

Frodin M, Antal TL, Dummler BA, Jensen CJ, Deak M, GAMMELTOFT S AND BIONDI RM. 2002. A phosphoserine/ threonine-binding pocket in AGC kinases and PDK1 mediates activation by hydrophobic motif phosphorylation. EMBO J 21: 5396-5407.

FUJII N ET AL. 2000. Exercise induces isoform-specific increase in $5^{\prime}$ AMP-activated protein kinase activity in human skeletal muscle. Biochemical and biophysical research communications 273: 1150-1155.

Fujil N, Hirshman MF, Kane EM, Ho RC, Peter LE, SeIfert MM AND GOODYEAR LJ. 2005. AMP-activated protein kinase alpha 2 activity is not essential for contraction- and hyperosmolarity-induced glucose transport in skeletal muscle. J Biol Chem 280: 39033-39041.

GAMBOA JL, GARCIA-CAZARIN ML AND ANDRADE FH. 2011. Chronic hypoxia increases insulin-stimulated glucose uptake in mouse soleus muscle. Am J Physiol Regul Integr Comp Physiol 300: R85-91.

GOODYEAR LJ, HiRshman MF, VALYOU PM AND HORTON ES. 1992. Glucose transporter number, function, and subcellular distribution in rat skeletal muscle after exercise training. Diabetes 41: 1091-1099.

GoOdyear LJ, King PA, Hirshman MF, ThOMPSON CM, HORTON ED AND HORTON ES. 1990. Contractile activity increases plasma membrane glucose transporters in absence of insulin. Am J Physiol 258: E667-672.

Guillausseau PJ, Meas T, Virally M, Laloi-Michelin M, Medeau V and KeVorkian JP. 2008. Abnormalities in insulin secretion in type 2 diabetes mellitus. Diabetes Metab 34 Suppl 2: S43-48

HALLSTEN K, VIRTANEN KA, LONNQVIST F, SIPILA H, OKSANEN A, Viljanen T, RonnemaA T, ViIKARI J, KnUUti J AND NUUTILA P. 2002. Rosiglitazone but not metformin enhances insulin- and exercise-stimulated skeletal muscle glucose uptake in patients with newly diagnosed type 2 diabetes. Diabetes 51: 3479-3485.

HAMM JK, El JACK AK, PILCH PF AND FARMER SR. 1999. Role of PPAR gamma in regulating adipocyte differentiation and insulin-responsive glucose uptake. Ann N Y Acad Sci 892: 134-145.
HARDIE DG. 2003. Minireview: the AMP-activated protein kinase cascade: the key sensor of cellular energy status. Endocrinology 144: 5179-5183.

HARDIE DG. 2008. AMPK: a key regulator of energy balance in the single cell and the whole organism. Int $\mathrm{J}$ Obes (Lond) 32 Suppl 4: S7-12.

HARDIE DG AND SAKAMOTO K. 2006. AMPK: a key sensor of fuel and energy status in skeletal muscle. Physiology (Bethesda) 21: 48-60.

HARDiE DG, Scott JW, PAN DA AND HudSON ER. 2003. Management of cellular energy by the AMP-activated protein kinase system. FEBS Lett 546: 113-120.

HAYASHI T, HIRSHMAN MF, KURTH EJ, WINDER WW AND GOODYEAR LJ. 1998. Evidence for 5' AMP-activated protein kinase mediation of the effect of muscle contraction on glucose transport. Diabetes 47: 13691373 .

HAYASHI T, WOJTASZEWSKI JF AND GOODYEAR LJ. 1997. Exercise regulation of glucose transport in skeletal muscle. Am J Physiol 273: E1039-1051.

Heinonen I, Nesterov SV, Kemppainen J, Fujimoto T, KNUUTI J AND KALLIOKOSKI KK. 2012. Increasing exercise intensity reduces heterogeneity of glucose uptake in human skeletal muscles. PLoS One 7: e52191.

HENRIKSEN EJ, JACOB S, Fogt DL AND DieTZE GJ. 1998. Effect of chronic bradykinin administration on insulin action in an animal model of insulin resistance. Am J Physiol 275: R40-45.

Henstridge DC, Drew BG, Formosa MF, Natoli AK, CAMERON-SMith D, DufFy SJ AND Kingwell BA. 2009. The effect of the nitric oxide donor sodium nitroprusside on glucose uptake in human primary skeletal muscle cells. Nitric oxide : biology and chemistry / official journal of the Nitric Oxide Society 21: 126-131.

HEVENER AL, REICHART D AND OLEFSKY J. 2000. Exercise and thiazolidinedione therapy normalize insulin action in the obese Zucker fatty rat. Diabetes 49: 2154-2159.

HigAKI Y, HiRshMAN MF, FUJII N AND GOODYEAR LJ. 2001. Nitric oxide increases glucose uptake through a mechanism that is distinct from the insulin and contraction pathways in rat skeletal muscle. Diabetes 50: 241-247.

Holloszy JO AND HANSEN PA. 1996. Regulation of glucose transport into skeletal muscle. Rev Physiol Biochem Pharmacol 128: 99-193.

Hughes VA, Fiatarone MA, Fielding RA, KahN BB, FERRARA CM, SHEPHERD P, FISHER EC, WOLFE RR, ElAHI D AND EVANS WJ. 1993. Exercise increases muscle GLUT-4 levels and insulin action in subjects with impaired glucose tolerance. Am J Physiol 264: E855-862.

IVY JL, ZDERIC TW AND FogT DL. 1999. Prevention and treatment of non-insulin-dependent diabetes mellitus. Exerc Sport Sci Rev 27: 1-35.

JACKSON MJ. 2008. Free radicals generated by contracting muscle: by-products of metabolism or key regulators of muscle function? Free Radic Biol Med 44: 132-141. 
JENSEN TE, Rose AJ, Hellsten Y, WoJtAszewsKi JF AND RiCHTER EA. 2007a. Caffeine-induced $\mathrm{Ca}(2+)$ release increases AMPK-dependent glucose uptake in rodent soleus muscle. Am J Physiol Endocrinol Metab 293: E286-292.

JENSEN TE, Rose AJ, JORGENSEN SB, BRANDT N, SCHJERLING P, WoJTASZEWSKI JF AND Richter EA. 2007b. Possible CaMKK-dependent regulation of AMPK phosphorylation and glucose uptake at the onset of mild tetanic skeletal muscle contraction. Am J Physiol Endocrinol Metab 292: E1308-1317.

JENSEN TE, SCHJERLING P, VIOLLET B, WOJTASZEWSKI JF AND RICHTER EA. 2008. AMPK alphal activation is required for stimulation of glucose uptake by twitch contraction, but not by $\mathrm{H} 2 \mathrm{O} 2$, in mouse skeletal muscle. PLoS One 3: e2102.

JESSEN N AND GoODYEAR LJ. 2005. Contraction signaling to glucose transport in skeletal muscle. J Appl Physiol 99: 330-337.

JI LL. 2008. Modulation of skeletal muscle antioxidant defense by exercise: Role of redox signaling. Free Radic Biol Med 44: 142-152.

JORGE ML ET AL. 2011. The effects of aerobic, resistance, and combined exercise on metabolic control, inflammatory markers, adipocytokines, and muscle insulin signaling in patients with type 2 diabetes mellitus. Metabolism 60: 1244-1252.

Jorgensen SB, Viollet B, Andreelli F, Frosig C, Birk JB, SChJERling P, VAUlONT S, Richter EA AND WOJTASZEWSKI JF. 2004. Knockout of the alpha2 but not alphal 5'-AMP-activated protein kinase isoform abolishes 5-aminoimidazole-4-carboxamide-1-beta-4-ribofuranosidebut not contraction-induced glucose uptake in skeletal muscle. J Biol Chem 279: 1070-1079.

Ju JS, Gitcho MA, Casmaer CA, Patil PB, Han DG, SPENCER SA AND FISHER JS. 2007. Potentiation of insulinstimulated glucose transport by the AMP-activated protein kinase. Am J Physiol Cell Physiol 292: C564-572.

Kadoglou NP, Iliadis F, Angelopoulou N, Perrea D, Ampatzidis G, Liapis CD AND Alevizos M. 2007. The anti-inflammatory effects of exercise training in patients with type 2 diabetes mellitus. Eur J Cardiovasc Prev Rehabil: official journal of the European Society of Cardiology, Working Groups on Epidemiology \& Prevention and Cardiac Rehabilitation and Exercise Physiology 14: 837-843.

Kane S, SANo H, LiU SC, Asara JM, LANE WS, Garner CC AND LIENHARD GE. 2002. A method to identify serine kinase substrates. Akt phosphorylates a novel adipocyte protein with a Rab GTPase-activating protein (GAP) domain. J Biol Chem 277: 22115-22118.

Kang L, DunN-Meynell AA, Routh VH, GASPERS LD, NAGATA Y, Nishimura T, EIKI J, ZHANG BB AND LEVIN BE. 2006. Glucokinase is a critical regulator of ventromedial hypothalamic neuronal glucosensing. Diabetes 55: 412-420.

KATZ A. 2007. Modulation of glucose transport in skeletal muscle by reactive oxygen species. J Appl Physiol 102: 1671-1676.
KAWAMORI R ET AL. 1998. Pioglitazone enhances splanchnic glucose uptake as well as peripheral glucose uptake in noninsulin-dependent diabetes mellitus. AD-4833 Clamp-OGL Study Group. Diabetes Res Clin Pract 41: 35-43.

KEMP BE ET AL. 2003. AMP-activated protein kinase, super metabolic regulator. Biochem Soc Trans 31: 162-168.

KENNEDY JW, HiRshman MF, GERVINO EV, OCEL JV, Forse RA, HOENIG SJ, ARONSON D, GOODYEAR LJ AND HORTON ES. 1999. Acute exercise induces GLUT4 translocation in skeletal muscle of normal human subjects and subjects with type 2 diabetes. Diabetes 48: 1192-1197.

King PA, Betts JJ, Horton ED And Horton ES. 1993. Exercise, unlike insulin, promotes glucose transporter translocation in obese Zucker rat muscle. Am J Physiol 265: R447-452.

KIRWAN JP AND DEL AGUILA LF. 2003. Insulin signalling, exercise and cellular integrity. Biochemical Society transactions 31: 1281-1285.

Kishi K, Muromoto N, Nakaya Y, Miyata I, Hagi A, HAYASHI H AND EBINA Y. 1998. Bradykinin directly triggers GLUT4 translocation via an insulin-independent pathway. Diabetes 47: 550-558.

KNOWLER WC, BARretT-CONNOR E, Fowler SE, Hamman RF, LACHIN JM, WALKER EA AND NATHAN DM. 2002. Reduction in the incidence of type 2 diabetes with lifestyle intervention or metformin. N Engl J Med 346: 393-403.

Kohn AD, Barthel A, Kovacina KS, Boge A, Wallach B, Summers SA, BIRNBAUM MJ, SCOTT PH, LAWRENCE Jr JC AND ROTH RA. 1998. Construction and characterization of a conditionally active version of the serine/threonine kinase Akt. J Biol Chem 273: 11937-11943.

Koistinen HA, GalusKa D, Chibalin AV, Yang J, Zierath JR, HOLMAN GD AND WALLBERG-HENRIKSSON H. 2003. 5-amino-imidazole carboxamide riboside increases glucose transport and cell-surface GLUT4 content in skeletal muscle from subjects with type 2 diabetes. Diabetes 52: 1066-1072.

Kramer HF, Witczak CA, FuJII N, Jessen N, TAYlor EB, ARnolds DE, SAKamoto K, Hirshman MF AND GOODYEAR LJ. 2006. Distinct signals regulate AS160 phosphorylation in response to insulin, AICAR, and contraction in mouse skeletal muscle. Diabetes 55: 20672076.

KRENTZ AJ AND BAILEY CJ. 2005. Oral antidiabetic agents: current role in type 2 diabetes mellitus. Drugs 65: 385-411.

KURTH-KraczeK EJ, HiRShMAN MF, GOOdYEAR LJ AND WINDER WW. 1999. 5' AMP-activated protein kinase activation causes GLUT4 translocation in skeletal muscle. Diabetes 48: 1667-1671.

LEE AD, HANSEN PA AND HollosZY JO. 1995. Wortmannin inhibits insulin-stimulated but not contraction-stimulated glucose transport activity in skeletal muscle. FEBS Lett 361: 51-54.

Li M, VERDiJK LB, SAKAMOTO K, ELy B, VAN LOON LJ AND MUSI N. 2012. Reduced AMPK-ACC and mTOR signaling in muscle from older men, and effect of resistance exercise. Mech Ageing Dev 133: 655-664. 
LIM J, ZHOU M, VEENSTRA TD AND MORRISON DK. 2010. The CNK1 scaffold binds cytohesins and promotes insulin pathway signaling. Genes Dev 24: 1496-1506.

Lund S, Holman GD, Schmitz O and Pedersen O. 1995. Contraction stimulates translocation of glucose transporter GLUT4 in skeletal muscle through a mechanism distinct from that of insulin. Proc Natl Acad Sci U S A 92: $5817-$ 5821.

Mackenzie R, Elliott B, MAXwell N, BRICKLEy G AND WATT P. 2012. The effect of hypoxia and work intensity on insulin resistance in type 2 diabetes. J Clin Endocrinol Metab 97: 155-162.

MatsaKas A AND PATEL K. 2009. Skeletal muscle fibre plasticity in response to selected environmental and physiological stimuli. Histol Histopathol 24: 611-629.

MCMURRAY RG AND HACKNEY AC. 2005. Interactions of metabolic hormones, adipose tissue and exercise. Sports Med 35: 393-412.

MERRY TL, LYNCH GS AND MCCONELL 2010a. GK Downstream mechanisms of nitric oxide-mediated skeletal muscle glucose uptake during contraction. Am J Physiol Regul Integr Comp Physiol 299: R1656-1665.

MerRy TL AND MCCONELl GK. 2012. Do Reactive Oxygen Species Regulate Skeletal Muscle Glucose Uptake During Contraction? Exerc Sport Sci Rev.

Merry TL, Steinberg GR, Lynch GS And MCCONell GK. 2010b. Skeletal muscle glucose uptake during contraction is regulated by nitric oxide and ROS independently of AMPK. Am J Physiol Endocrinol Metab 298: E577-585.

Merry TL, WADley GD, Stathis CG, Garnham AP, RATTIGAN S, HARGREAVES M AND MCCONELL GK. 2010c. N-Acetylcysteine infusion does not affect glucose disposal during prolonged moderate-intensity exercise in humans. J Physiol 588: 1623-1634.

Milburn CC, DeAK M, Kelly SM, Price NC, Alessi DR AND VAN AALTEN DM. 2003. Binding of phosphatidylinositol 3,4,5-trisphosphate to the pleckstrin homology domain of protein kinase $\mathrm{B}$ induces a conformational change. Biochem J 375: 531-538.

MinOKOSHI Y ET AL. 2004. AMP-kinase regulates food intake by responding to hormonal and nutrient signals in the hypothalamus. Nature 428: 569-574.

Misra A, Singhal N AND KhURANA L. 2010. Obesity, the metabolic syndrome, and type 2 diabetes in developing countries: role of dietary fats and oils. J Am Coll Nutr 29: 289S-301S.

MiYAmOTO L ET AL. 2007. Effect of acute activation of 5'-AMPactivated protein kinase on glycogen regulation in isolated rat skeletal muscle. J Appl Physiol 102: 1007-1013.

Moncada S AND Higgs A. 1993. The L-arginine-nitric oxide pathway. N Engl J Med 329: 2002-2012.

MOR V AND UNNIKRISHNAN MK. 2011. 5'-adenosine monophosphate-activated protein kinase and the metabolic syndrome. Endocr Metab Immune Disord Drug Targets 11: 206-216.
Motoshima H ET AL. 2000. Bradykinin enhances insulin receptor tyrosine kinase in $32 \mathrm{D}$ cells reconstituted with bradykinin and insulin signaling pathways. Diabetes Res Clin Pract 48: 155-170.

Mu J, Brozinick Jr JT, Valladares O, Bucan M And BIRNBAUM MJ. 2001. A role for AMP-activated protein kinase in contraction- and hypoxia-regulated glucose transport in skeletal muscle. Mol Cell 7: 1085-1094.

MUSI N AND GOODYEAR LJ. 2003. AMP-activated protein kinase and muscle glucose uptake. Acta Physiol Scand 178: $337-345$

MUSI N ET AL. 2002. Metformin increases AMP-activated protein kinase activity in skeletal muscle of subjects with type 2 diabetes. Diabetes 51: 2074-2081.

NARKAR VA ET AL. 2008. AMPK and PPARdelta agonists are exercise mimetics. Cell 134: 405-415.

NATALI A AND FERRANNINI E. 2006. Effects of metformin and thiazolidinediones on suppression of hepatic glucose production and stimulation of glucose uptake in type 2 diabetes: a systematic review. Diabetologia 49: 434-441.

NiSSEN SE AND WOLSKI K. 2007. Effect of rosiglitazone on the risk of myocardial infarction and death from cardiovascular causes. N Engl J Med 356: 2457-2471.

NORRIS SM, BOMBARDIER E, SMITH IC, VIGNA C AND TUPLING AR. 2012. ATP consumption by sarcoplasmic reticulum $\mathrm{Ca} 2+$ pumps accounts for $50 \%$ of resting metabolic rate in mouse fast and slow twitch skeletal muscle. Am J Physiol Cell Physiol 298: C521-529.

OJUKA EO. 2004. Role of calcium and AMP kinase in the regulation of mitochondrial biogenesis and GLUT4 levels in muscle. Proc Nutr Soc 63: 275-278.

OJuka EO, Jones TE, Nolte LA, Chen M, WAMHoff BR, STUREK M AND Holloszy JO. 2002. Regulation of GLUT4 biogenesis in muscle: evidence for involvement of AMPK and $\mathrm{Ca}(2+)$. Am J Physiol Endocrinol Metab 282: E1008-1013.

OWEN MR, DORAN E AND HALESTRAP AP. 2000. Evidence that metformin exerts its anti-diabetic effects through inhibition of complex 1 of the mitochondrial respiratory chain. Biochem J 348 Pt 3: 607-614.

Pehmoller C, Treebak JT, Birk JB, Chen S, Mackintosh C, HARdiE DG, Richter EA AND WoJTASZEWSKI JF. 2009. Genetic disruption of AMPK signaling abolishes both contraction- and insulin-stimulated TBC1D1 phosphorylation and 14-3-3 binding in mouse skeletal muscle. Am J Physiol Endocrinol Metab 297: E665-675.

Phielix E, Szendroedi J And Roden M. 2011. The role of metformin and thiazolidinediones in the regulation of hepatic glucose metabolism and its clinical impact. Trends Pharmacol Sci 32: 607-616.

POWERS SK AND JACKSON MJ. 2008. Exercise-induced oxidative stress: cellular mechanisms and impact on muscle force production. Physiol Rev 88: 1243-1276.

RAZANI B, CHAKRAVARTHY MV AND SEMENKOVICH CF. 2008 Insulin resistance and atherosclerosis. Endocrinol Metab Clin North Am 37: 603-621, viii. 
REICHKENDLER MH ET AL. 2013. Exercise training favors increased insulin-stimulated glucose uptake in skeletal muscle in contrast to adipose tissue: a randomized study using FDG PET imaging. Am J Physiol Endocrinol Metab 305: E496-506.

RENNIE MJ. 2007. Exercise- and nutrient-controlled mechanisms involved in maintenance of the musculoskeletal mass. Biochem Soc Trans 35: 1302-1305.

Richter EA, DERAVE W AND WoJTASZEWSKi JF. 2001. Glucose, exercise and insulin: emerging concepts. J Physiol 535: 313-322.

Richter EA AND HARgReAVES M. 2012. Exercise, GLUT4, and skeletal muscle glucose uptake. Physiol Rev 93: 9931017.

Richter EA, Nielsen JN, Jorgensen SB, Frosig C, BiRK JB AND WOJTASZEWSKI JF. 2004. Exercise signalling to glucose transport in skeletal muscle. Proc Nutr Soc 63: 211-216.

RizZA R AND BUTLER P. 1990. Insulin resistance in type II diabetes mellitus. Adv Second Messenger Phosphoprotein Res 24: 511-516.

ROBERTS CK, BARNARD RJ, SCHECK SH AND BALON TW. 1997. Exercise-stimulated glucose transport in skeletal muscle is nitric oxide dependent. Am J Physiol 273: E220-225.

Rothman DL, Magnusson I, Cline G, Gerard D, KaHN CR, SHulman RG AND Shulman GI. 1995. Decreased muscle glucose transport/phosphorylation is an early defect in the pathogenesis of non-insulin-dependent diabetes mellitus. Proc Natl Acad Sci U S A 92: 983-987.

ROWLAND AF, FAZAKERLEY DJ AND JAMES DE. 2011. Mapping insulin/GLUT4 circuitry. Traffic 12: 672-681.

Roy D, Perreault M AND Marette A. 1998. Insulin stimulation of glucose uptake in skeletal muscles and adipose tissues in vivo is NO dependent. Am J Physiol 274: E692-699.

SAlt IP, Johnson G, AshCroft SJ AND Hardie DG. 1998. AMP-activated protein kinase is activated by low glucose in cell lines derived from pancreatic beta cells, and may regulate insulin release. Biochem J 335(3): 533-539.

SANDSTROM ME, ZhANG SJ, BRUTON J, Silva JP, REID MB, Westerblad H AND KATZ A. 2006. Role of reactive oxygen species in contraction-mediated glucose transport in mouse skeletal muscle. J Physiol 575: 251-262.

Sano H, Kane S, SAno E, Minnea CP, Asara JM, Lane WS, GARNER CW AND LIENHARD GE. 2003. Insulin-stimulated phosphorylation of a Rab GTPase-activating protein regulates GLUT4 translocation. J Biol Chem 278: 1459914602.

SANTOS JM, Ribeiro SB, GAYA AR, APPELl HJ AND DUARTE JA. 2008. Skeletal muscle pathways of contractionenhanced glucose uptake. Int J Sports Med 29: 785-794.

SARbassov DD, Guertin DA, Ali SM AND SABATINI DM. 2005. Phosphorylation and regulation of Akt/PKB by the rictor-mTOR complex. Science 307: 1098-1101.

Schultze SM, Hemmings BA, Niessen M AND Tschopp O. 2012. PI3K/AKT, MAPK and AMPK signalling: protein kinases in glucose homeostasis. Expert Rev Mol Med 14: e1.
SHAH AK, GUPTA A AND DEY CS. 2011. AICAR induced AMPK activation potentiates neuronal insulin signaling and glucose uptake. Arch Biochem Biophys 509: 142-146.

SHEIBANI S, HANACHI P AND REFAHIAT MA. 2012. Effect of Aerobic Exercise on Serum Concentration of Apelin, TNFalpha and Insulin in Obese Women. Iran J Basic Med Sci 15: 1196-1201.

SHEIBANI S, HANACHI P AND REFAHIAT MA. 2012. Effect of Aerobic Exercise on Serum Concentration of Apelin, TNFalpha and Insulin in Obese Women. Iran J Basic Med Sci 15: 1196-1201.

SHEPHERD PR AND KAHN BB. 1999. Glucose transporters and insulin action--implications for insulin resistance and diabetes mellitus. N Engl J Med 341: 248-257.

ShIUCHI T, CUI TX, WU L, NAKAgAmi H, TAKEDA-MATSUBARA Y, IWAI MAND HORIUCHI M. 2002. ACE inhibitor improves insulin resistance in diabetic mouse via bradykinin and NO. Hypertension 40: 329-334.

SHIUChI T, NAKAGAMI H, IwaI M, TAKEDA Y, CUI T, CHEN R, MINOKOSHI Y AND HORIUCHI M. 2001. Involvement of bradykinin and nitric oxide in leptin-mediated glucose uptake in skeletal muscle. Endocrinology 142: 608-612.

SRIWIJITKAMOL A AND MUSI N. 2008. Advances in the development of AMPK-activating compounds. Expert Opin Drug Discov 3: 1167-1176.

Szekeres F, Chadt A, Tom RZ, Deshmukh AS, Chibalin AV, BJoRnholm M, AL-HASANI H AND ZIERATH Jr. 2012. The Rab-GTPase-activating protein TBC1D1 regulates skeletal muscle glucose metabolism. Am J Physiol Endocrinol Metab 303: E524-533.

TANAKA TETAL. 2003. Nitric oxide stimulates glucose transport through insulin-independent GLUT4 translocation in 3T3-L1 adipocytes. Eur J Endocrinol 149: 61-67.

TAYLOR EB ET AL. 2008. Discovery of TBC1D1 as an insulin-, AICAR-, and contraction-stimulated signaling nexus in mouse skeletal muscle. J Biol Chem 283: 9787-9796.

Terada S, Muraoka I And Tabata I. 2003. Changes in $[\mathrm{Ca} 2+] \mathrm{i}$ induced by several glucose transport-enhancing stimuli in rat epitrochlearis muscle. J Appl Physiol 94: 1813-1820.

ThONG FS, DUGANi CB AND KLIP A. 2005. Turning signals on and off: GLUT4 traffic in the insulin-signaling highway. Physiology (Bethesda) 20: 271-284.

VAN DAM EM, GOVERS R AND JAMES DE. 2005. Akt activation is required at a late stage of insulin-induced GLUT4 translocation to the plasma membrane. Mol Endocrinol 19: 1067-1077.

Viollet B, Guigas B, Sanz Garcia N, Leclerc J, Foretz M AND ANDREelli F. 2012. Cellular and molecular mechanisms of metformin: an overview. Clin Sci (Lond) 122: 253-270.

Vogt B, Muhlbacher C, CARrascosa J, Obermaier-Kusser B, Seffer E, Mushack J, Pongratz D and Haring HU. 1992. Subcellular distribution of GLUT 4 in the skeletal muscle of lean type 2 (non-insulin-dependent) diabetic patients in the basal state. Diabetologia 35: 456-463. 
WestPhal SA. 2008. Obesity, abdominal obesity, and insulin resistance. Clin Cornerstone 9: 23-29; discussion 30-21.

WHEATLEY CM, RATTIGAN S, RICHARDS SM, BARRETT EJ AND CLARK MG. 2004. Skeletal muscle contraction stimulates capillary recruitment and glucose uptake in insulinresistant obese Zucker rats. Am J Physiol Endocrinol Metab 287: E804-809.

WhITE MF AND KAHN CR. 1994. The insulin signaling system. J Biol Chem 269: 1-4.

WiJesekara N, Tung A, Thong F And Klip A. 2006. Muscle cell depolarization induces a gain in surface GLUT4 via reduced endocytosis independently of AMPK. Am J Physiol Endocrinol Metab 290: E1276-1286.

WINDER WW AND HARDIE DG. 1996. Inactivation of acetylCoA carboxylase and activation of AMP-activated protein kinase in muscle during exercise. The American journal of physiology 270: E299-304.

WoJTASZEWSKi JF, MACDONALd C, NiELSEN JN, Hellsten Y, HARDIE DG, KEMP BE, KiENS B AND Richter EA. 2003. Regulation of 5'AMP-activated protein kinase activity and substrate utilization in exercising human skeletal muscle. American journal of physiology Endocrinology and metabolism 284: E813-822.

Wright DC, Geiger PC, Holloszy JO AND HaN DH. 2005. Contraction- and hypoxia-stimulated glucose transport is mediated by a $\mathrm{Ca} 2+$-dependent mechanism in slow-twitch rat soleus muscle. Am J Physiol Endocrinol Metab 288: E1062-1066.

Wright DC, HUCKER KA, Holloszy JO AND HAN DH. 2004. $\mathrm{Ca} 2+$ and AMPK both mediate stimulation of glucose transport by muscle contractions. Diabetes 53: 330-335.
Ye JM, DZAmKo N, Hoy AJ, Iglesias MA, KemP B AND KRAEGEN E. 2006. Rosiglitazone treatment enhances acute AMP-activated protein kinase-mediated muscle and adipose tissue glucose uptake in high-fat-fed rats. Diabetes 55: 2797-2804.

Youn JH, Gulve EA AND Holloszy JO. 1991. Calcium stimulates glucose transport in skeletal muscle by a pathway independent of contraction. Am J Physiol 260: C555-561.

Zang M, Zuccollo A, Hou X, Nagata D, Walsh K, HERSCOVITZ H, BRECHER P, RUDERMAN NB AND COHEN RA. 2004. AMP-activated protein kinase is required for the lipid-lowering effect of metformin in insulin-resistant human HepG2 cells. J Biol Chem 279: 47898-47905.

ZHOU G ET AL. 2001. Role of AMP-activated protein kinase in mechanism of metformin action. J Clin Invest 108: 11671174.

Zierath Jr, He L, Guma A, Odegoard Wahlstrom E, KliP A AND WALLBERG-HENRIKSSON H. 1996. Insulin action on glucose transport and plasma membrane GLUT4 content in skeletal muscle from patients with NIDDM. Diabetologia 39: 1180-1189.

Zou MH, Kirkpatrick SS, Davis BJ, Nelson JS, Wiles WGT, Schlattner U, NeumanN D, BrownleE M, FREEMAN MB AND GOLDMAN MH. 2004. Activation of the AMP-activated protein kinase by the anti-diabetic drug metformin in vivo. Role of mitochondrial reactive nitrogen species. J Biol Chem 279: 43940-43951. 